\title{
PENGOLAHAN AIR LIMBAH TEKSTIL MELALUI PROSES \\ KOAGULASI - FLOKULASI DENGAN MENGGUNAKAN LEMPUNG SEBAGAI PENYUMBANG PARTIKEL TERSUSPENSI \\ Studi Kasus: Banaran, Sukoharjo dan Lawean, Kerto Suro, Jawa Tengah

\author{
TEXTILES WASTEWATER TREATMENT BY COAGULATION - \\ FLOCCULATION PROCESSWITH THE USE OF CLAY AS THE CONTRIBUTOR \\ OF SUSPENDED PARTICLES \\ Case Study: Banaran, Sukoharjo and Lawean, Kerto Suro, Central Java
}

Anna Fadliah Rusydi, Dadan Suherman, dan Nyoman Sumawijaya

Pusat Penelitian Geoteknologi LIPI, Komplek LIPI, Jl. Sangkuriang, Bandung

E-mail: anna.fadliah.rusydi@lipi.go.id

Tanggal diterima: 4 Oktober 2016, direvisi: 8 Maret 2017, disetujui terbit: 22 Maret 2017

\begin{abstract}
ABSTRAK
Air tanah dangkal di Banaran Sukoharjo dan Lawean Kerto Suro, Jawa Tengah, telah tercemar zat organik yang ditandai dengan tingginya kandungan COD. Kandungan COD dalam airtanah berkisar antara $9.8 \mathrm{mg} / \mathrm{L}$ sampai $150 \mathrm{mg} / \mathrm{L}$. Salah satu penyebab tingginya COD adalah pembuangan air limbah dari industri tekstil tanpa pengolahan ke lingkungan yang kemudian bergerak hingga mencapai airtanah. Pengolahan air limbah sebelum dibuang ke lingkungan merupakan cara yang tepat untuk mengatasi masalah pencemaran ini. Metode yang digunakan dalam penelitian ini adalah sistem batch melalui proses koagulasi-flokulasi. Percobaan diawali dengan penambahan kaporit dan kapur untuk menurunkan intensitas warna, kemudian tanah lempung untuk menaikkan kandungan partikelpartikel tersuspensi, dan penambahan tawas sebagai koagulan. Penambahan $2 \mathrm{~g}$ kaporit; $0.3 \mathrm{~g}$ kapur; $1 \mathrm{~g}$ lempung; dan $1 \mathrm{~g}$ tawas ke dalam $500 \mathrm{ml}$ air limbah, pada pengadukan $200 \mathrm{rpm}$ selama 2 menit, berhasil menurunkan COD sebesar 79\% yakni dari $615 \mathrm{mg} / \mathrm{L}$ menjadi $130 \mathrm{mg} / \mathrm{L}$, dan warna sebesar 99\% yakni dari 7000 PCU menjadi 45 PCU. Penurunan COD dan warna pada air limbah akan meminimalkan dan mencegah terjadinya pencemaran airtanah, karena kandungan COD $130 \mathrm{mg} / \mathrm{L}$ telah memenuhi baku mutu limbah. Warna belum tercantum dalam bakumutu limbah, namun dengan kondisi air limbah yang sudah tidak berwarna maka limbah telah memenuhi syarat dari segi estetika.
\end{abstract}

Kata kunci: tekstil, koagulasi, flokulasi, dosis, partikel tersuspensi, COD, warna, pH

\begin{abstract}
Shallow groundwater in Banaran Sukoharjo and Lawean Kerto Suro, Central Java, have been contaminated by organic matter which was characterized by a high content of COD with a value of $9.8 \mathrm{mg} / \mathrm{L}$ to $150 \mathrm{mg} / \mathrm{L}$. One of the causes of high COD was the discharge of untreated wastewater from textile industries into the environment without treatment which then moves until it reaches groundwater. Wastewater treatment before release into the environment is the right way to solve this contamination problem. The method used in this study is a batch system through coagulation-flocculation process. The experiment begins with the addition of calcium hypochlorite and lime to reduce the intensity of the color, then clay to raise the content of suspended particles, and alum as a coagulant. The addition of $2 \mathrm{~g}$ of chlorine; $0.3 \mathrm{~g}$ of lime; $1 \mathrm{~g}$ of clay; and $1 \mathrm{~g}$ of alumunium sulfate in $500 \mathrm{ml}$ of wastewater, with stirring process $200 \mathrm{rpm}$ for 2 minutes, has successfully reduce the COD about 79\%, from $615 \mathrm{mg} / \mathrm{L} \mathrm{to} 130 \mathrm{mg} / \mathrm{L}$, and colors about 99\%, from 7,000 PCU to 45 PCU. COD and color reduction from the wastewater will minimize and prevent groundwater pollution, because COD with value $130 \mathrm{mg} / \mathrm{L}$ has met the wastewater quality standard. Color is not listed in wastewater standard but with the condition of the wastewater that colorless so the waste is aesthetically qualified.
\end{abstract}

Keywords: textile, coagulation, flocculation, dose, suspended particles, COD, color, $\mathrm{pH}$ 


\section{PENDAHULUAN}

Pencemaran air akibat limbah industri tekstil merupakan masalah yang sering terjadi di negaranegara berkembang dunia, salah satunya Indonesia. ${ }^{1}$ Jika dibandingkan dengan negara-negara di Asia Tenggara lainnya, Indonesia merupakan negara dengan beban air limbah industri tekstil terbesar. Beban air limbah organik yang dihasilkan di Indonesia adalah sebesar 883 ton/hari, yang mana $29 \%$ dari beban ini berasal dari industri tekstil. ${ }^{2}$

Industri tekstil biasanya menghasilkan limbah cair yang berwarna pekat serta mengandung BOD (biochemical oxygen demand), COD (chemical oxygen demand), $\mathrm{pH}$, temperatur, turbiditas, salinitas, dan bahan kimia toksik yang tinggi dan berfluktuasi. ${ }^{3,4,5}$ Air limbah tersebut menimbulkan dampak negatif, baik langsung maupun tidak langsung, apabila dibuang ke lingkungan tanpa pengolahan. ${ }^{3,6}$ Salah satu dampak langsungnya adalah pencemaran airtanah dangkal akibat proses pergerakan air limbah dari permukaan ke dalam tanah. Dampak ini telah terlihat di lokasi penelitian, yakni industri tekstil di Banaran Sukoharjo dan Lawean Kerto Suro Jawa Tengah. Banaran dan Lawean merupakan sentra industri batik di Indonesia yang umumnya dilakukan dalam skala rumah (homescale industry). Industri tersebut menghasilkan banyak air limbah yang sebagian besar berasal dari proses pencelupan dan pencucian kain. Permasalahan kemudian timbul karena air limbah umumnya dibuang langsung ke lingkungan tanpa pengolahan. Air limbah tersebut memiliki warna sangat pekat dan nilai COD tinggi $( \pm 600$ $\mathrm{mg} / \mathrm{L}$ ) sehingga mencemari airtanah dangkal di sekitarnya. Hal ini terlihat dari tingginya kandungan COD pada airtanah dangkal. Hasil penelitian menunjukkan nilai COD pada airtanah dangkal terendah adalah $9.8 \mathrm{mg} / \mathrm{L}$ dan tertinggi mencapai $150 \mathrm{mg} / \mathrm{L}^{7}$

Hasil analisis hidrogeologi di lokasi penelitian menunjukkan bahwa tanah memiliki laju infiltrasi lambat ${ }^{8}$. Nilai laju infiltrasi menunjukkan kemampuan tanah untuk melewatkan cairan dari permukaan tanah secara vertikal. ${ }^{9}$ Tanah dengan nilai infiltrasi lambat harusnya dapat menahan pergerakan pencemar mencemari airtanah. Namun, tanah juga memiliki kapasitas jenuh yang mana saat kapasitas ini sudah tercapai maka pencemar dalam air dapat lolos ke dalam airtanah. Pada kondisi ini semua jenis pencemar dapat masuk ke dalam airtanah, termasuk limbah domestik sebagai pencemar organik. Namun demikian, pencemar yang berasal dari limbah industri umumnya memberikan kontribusi organik yang lebih tinggi dibandingkan limbah lain. Seperti halnya kualitas airtanah dangkal (sumur-sumur gali) di daerah penelitian sekitar lokasi industri pencelupan menunjukkan kandungan COD sampai $150 \mathrm{mg} / \mathrm{L}$. Dalam mengatasi permasalahan tersebut perlu dilakukan pengolahan air limbah untuk menurunkan nilai COD dan mengurangi intensitas warna limbah yang pekat untuk mencegah terjadinya pencemaran airtanah yang lebih serius.

Koagulasi - flokulasi merupakan salah satu proses pengolahan air limbah yang dapat digunakan dalam penelitian ini. Pemilihan ini dikarenakan prosesnya yang sederhana, mudah diaplikasikan, biaya relatif murah, dan mampu mengolah limbah hingga memenuhi baku mutu. ${ }^{1,10}$ Koagulasi adalah proses penambahan koagulan atau zat kimia ke dalam suatu larutan dengan tujuan untuk mengkondisikan suspensi, koloid, dan materi tersuspensi dalam persiapan proses lanjutan yaitu flokulasi. ${ }^{11,12}$ Flokulasi adalah proses pengumpulan partikel-partikel dengan muatan tidak stabil yang kemudian saling bertubrukan sehingga membentuk kumpulan partikel-partikel dengan ukuran yang lebih besar, juga dikenal dengan istilah partikel flokulan atau flok. $^{12}$

Pada beberapa jenis limbah cair tekstil, salah satunya limbah yang berkarakteristik bening, proses koagulasi - flokulasi tidak bisa diterapkan dengan baik karena larutan yang bening miskin akan partikel-partikel (materi) tersuspensi (pembentuk koloid). Oleh karena itu, proses ini perlu dilakukan secara bertahap yakni dengan terlebih dahulu menaikkan kandungan partikel-partikel tersuspensi melalui penambahan tanah lempung. Tujuan dari penelitian untuk menemukan dosis bahan kimia (kapur, kaporit, tanah lempung, tawas) yang tepat dalam mengolah air limbah tekstil guna menurunkan intensitas kadar COD dan warna sampai memenuhi baku mutu limbah agar aman dibuang ke lingkungan.

\section{METODE \\ Bahan}

Pengolahan dilakukan dengan sistem batch dengan menambahkan bahan kimia ke dalam 500 $\mathrm{mL}$ air limbah pada gelas beker berukuran 1000 $\mathrm{mL}$. Air limbah diambil dari outlet industri pencelupan. Bahan kimia yang ditambahkan adalah kaporit, kapur $(\mathrm{CaO})$, lempung, dan tawas. Pemilihan bahan kimia dalam pengolahan ini didasarkan pada penelitian yang telah dilakukan Suherman (2013) mengenai pengolahan air gambut. ${ }^{13}$ Air gambut memiliki sifat fisik yang sama dengan air limbah tekstil, yakni miskin partikel tersuspensi.

Bahan kimia kaporit, kapur, dan tawas merupakan bahan-bahan yang ditemukan di pasaran dan dapat langsung digunakan dalam proses koagulasi - flokulasi. Sementara lempung, merupakan bahan alami yang harus diproses sebelum ditambahkan ke dalam air limbah. Proses penyiapan lempung dilakukan dengan pengeringan dalam oven pada suhu $100-105^{\circ} \mathrm{C}$, kemudian ditumbuk, dan diayak pada ayakan yang lolos pada 
ukuran 100 mesh (-100 mesh). Selanjutnya dilakukan analisis fisik lempung. Hal ini penting, karena keberhasilan lempung dalam memperkaya kandungan partikel-partikel tersuspensi tergantung pada kandungan debu dan liat. Semakin banyak kandungan debu dan liat, maka penambahan lempung akan semakin membantu dalam memperkaya partikel-partikel tersuspensi dalam air limbah.
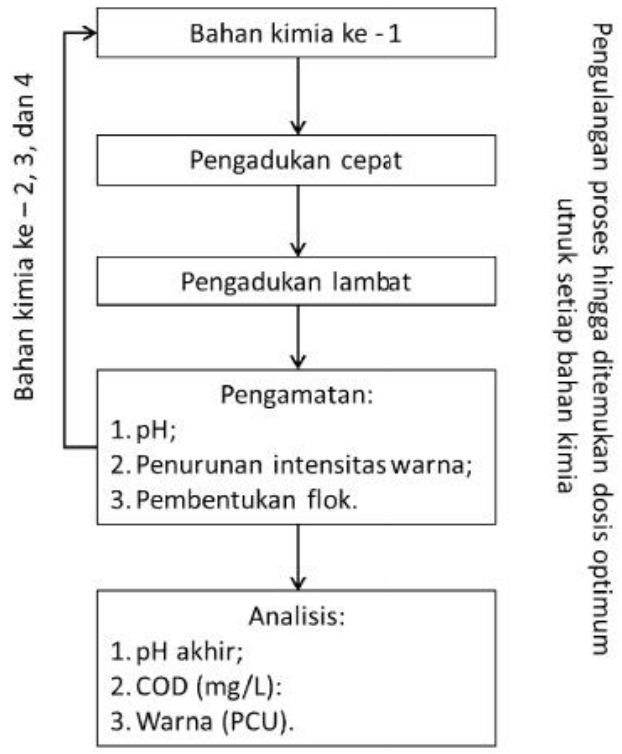

Gambar 1. Tahapan proses koagulasi - flokulasi

Seperti terlihat pada Gambar 1, setelah penambahan bahan kimia kemudian dilakukan pengadukan menggunakan pengaduk magnet dengan kecepatan $200 \mathrm{rpm}$ selama 2 menit. Pengadukan ini disebut sebagai pengadukan cepat. Selanjutnya, dilakukan pengadukan lambat yaitu pada saat kecepatan diturunkan perlahan hingga 0 rpm. Pada setiap penambahan bahan kimia dilakukan pengamatan dan analisis seperti pada Tabel 1.

Tabel 1. Pengamatan setelah penambahan bahan kimia pada proses koagulasi dan flokulasi

\begin{tabular}{|c|c|}
\hline Penambahan & Pengamatan dan analisis \\
\hline 1. Kaporit & $\begin{array}{ll}- & \text { pH. } \\
\text { - } & \text { penurunan / perubahan warna. } \\
\text { - } & \text { pembentukan flok. }\end{array}$ \\
\hline 2. Kapur & $\begin{array}{l}\text { - pH. } \\
\text { - pembentukan flok. }\end{array}$ \\
\hline 3. Lempung & \\
\hline 4. Tawas & $\begin{array}{l}\text { - pH akhir. } \\
\text { - pembentukan flok. } \\
\text { - COD dan warna }\end{array}$ \\
\hline
\end{tabular}

\section{Penentuan dosis awal}

Dalam penentuan dosis optimum masingmasing bahan kimia dilakukan dengan cara menjadikan bahan kimia tertentu sebagai variabel tidak tetap dan bahan-bahan kimia lain sebagai variabel tetap. Tabel 2 memperlihatkan dosis awal untuk masing-masing bahan kimia.

Tabel 2. Dosis awal untuk setiap bahan kimia

\begin{tabular}{|c|c|c|}
\hline $\begin{array}{l}\text { Penentuan } \\
\text { dosis awal }\end{array}$ & $\begin{array}{c}\text { Variabel tidak } \\
\text { tetap }(\mathrm{g})\end{array}$ & $\begin{array}{c}\text { Variabel tetap } \\
\text { (g) }\end{array}$ \\
\hline 1. Kaporit & $\begin{array}{l}\text { - kaporit: } \\
0.5 ; 1 ; 1.5 ; 2 .\end{array}$ & $\begin{array}{l}\text { - Kapur:0.5 } \\
\text { - Lempung: } 1 \\
\text { - Tawas: } 1\end{array}$ \\
\hline 2. Kapur & $\begin{array}{l}\text { - Kapur: } \\
0.1 ; 0.2 ; 0.3 \\
0.4\end{array}$ & $\begin{array}{l}\text { - Kaporit :2 } \\
\text { - Lempung: } 1 \\
\text { - Tawas : } 1\end{array}$ \\
\hline 3.Lempung & $\begin{array}{l}\text { - Lempung: } \\
1.5 ; 2 ; 2.5 ; 3 .\end{array}$ & $\begin{array}{l}\text { - Kaporit : } 2 \\
\text { - Kapur:0.5 } \\
\text { - Tawas : } 1\end{array}$ \\
\hline 4. Tawas & $\begin{array}{l}\text { - Tawas: } \\
0.5 ; 1 ; 1.5\end{array}$ & $\begin{array}{l}\text { - Kaporit : } 2 \\
\text { - Kapur: } 0.5 \\
\text { - Lempung: } 1\end{array}$ \\
\hline
\end{tabular}

Penambahan masing-masing zat kimia memiliki tujuan sebagai berikut:

1. Kaporit

Kaporit merupakan zat kimia yang pertama kali ditambahkan dan bertujuan untuk memutus ikatan rangkap pada gugus fungsi zat warna sehingga terjadi reaksi addisi oleh $\mathrm{Cl}_{2}$ dari kaporit. Proses kimiawi kaporit dalam memutus ikatan rangkap zat warna dijelaskan pada bagian pembahasan.

2. Kapur

Penambahan kapur bertujuan untuk menaikkan nilai $\mathrm{pH}$ karena kondisi basa akan mengoptimumkan fungsi koagulan tawas.

3. Lempung

Lempung bertujuan untuk memperkaya partikelpartikel tersuspensi dalam limbah karena limbah yang diolah secara fisik bersifat bening (miskin partikel tersuspensi).

4. Tawas

Tawas berfungsi sebagai koagulan yang mengikat partikel-partikel tersuspensi yang berasal dari penambahan lempung sehingga terjadi proses koagulasi dan flokulasi.

\section{Penentuan dosis optimum}

Penentuan dosis optimum didasarkan pada hasil pengamatan $\mathrm{pH}$, serta analisis COD dan warna setelah proses koagulasi dan flokulasi. Dosis optimum diperoleh berdasarkan penurunan COD dan warna yang paling signifikan. Analisis COD dan warna dilakukan sesuai Standard Method 21 (1995) dengan metode reflux tertutup untuk pemeriksaan COD dan spektrofotometri sinar tampak untuk pemeriksaan warna. ${ }^{14}$ Hasil analisis kandungan $\mathrm{COD}$ dan $\mathrm{pH}$ air limbah setelah pengolahan selanjutnya dibandingkan dengan baku mutu limbah cair industri tekstil dan batik yang diatur dalam Perda Provinsi Jawa Tengah No. 5 
Tahun 2012. ${ }^{15}$ Dalam peraturan tersebut dicantumkan baku mutu $\mathrm{pH}$ yang aman adalah pada rentang 6 s.d 9 dan kandungan COD maksimum adalah $150 \mathrm{mg} / \mathrm{L}$. Sementara parameter warna belum diatur dalam peraturan ini.

\section{HASIL DAN PEMBAHASAN}

\section{Karakteristik air limbah}

Air limbah yang diolah memiliki karakteristik sebagai berikut: (i) $\mathrm{pH}=8,3$; (ii) COD $=615 \mathrm{mg} / \mathrm{L}$, dan (iii) intensitas warna $=7000 \mathrm{PCU}$ (platina cobalt unit). Nilai $\mathrm{pH}$ limbah yang diolah masih memenuhi persyaratan, sedangkan nilai COD limbah 76 kali di atas baku mutu maksimum. Warna limbah meskipun bening secara fisik, namun sangat gelap dan akan mengganggu estetika apabila dibuang langsung ke lingkungan. Oleh karena itu, pada penelitian ini warna termasuk parameter yang penting untuk diproses meskipun belum diatur dalam baku mutu limbah cair.

\section{Penentuan dosis kaporit}

Gambar 2 memperlihatkan penurunan kandungan COD setelah penambahan kaporit: (i) penambahan $0.5 \mathrm{~g}$, COD turun dari $615 \mathrm{mg} / \mathrm{L}$ menjadi $270 \mathrm{mg} / \mathrm{L}(56 \%)$; (ii) penambahan $1 \mathrm{~g}$, COD turun menjadi $250 \mathrm{mg} / \mathrm{L} \quad(59 \%)$; (iii) penambahan $1.5 \mathrm{~g}$, COD turun menjadi $200 \mathrm{mg} / \mathrm{L}$ (67\%); dan (iv) penambahan $2 \mathrm{~g}$, mampu menurunkan COD hingga $70 \mathrm{mg} / \mathrm{L}$ (89\%). Intensitas warna juga mengalami penurunan seiring dengan penurunan COD, yaitu: (i) saat penambahan $0.5 \mathrm{~g}$, intensitas warna dari $7000 \mathrm{PCU}$ turun menjadi 350 PCU (95\%); (ii) penambahan $1 \mathrm{~g}$, warna turun menjadi 340 PCU (95\%); (iii) penambahan $1.5 \mathrm{~g}$, warna turun menjadi $125 \mathrm{PCU}$ (98\%); dan (iv) penambahan $2 \mathrm{~g}$, warna turun menjadi 100 PCU (99\%) (Gambar 3).

Nilai COD dan intensitas warna terendah diperoleh pada dosis kaporit 2 g. Pada dosis tersebut, COD turun hingga mencapai $89 \%$ dan warna mencapai 99\%. Kemudian, dari pengamatan flok terlihat ukuran yang terbentuk berukuran \pm 0.3 $\mathrm{cm}$ dan mengendap dengan baik di dasar baker glass. Dengan demikian, dosis kaporit $2 \mathrm{~g}$ digunakan untuk percobaan selanjutnya yaitu penetapan dosis bahan kimia lainnya.

Saat kaporit ditambahkan ke dalam limbah, terjadi penurunan intensitas warna yang signifikan dari berwarna gelap menjadi hampir tidak berwarna. Peristiwa ini menunjukkan terjadi perubahan struktur dari gugus fungsi zat warna. Proses penurunan intensitas warna karena penambahan kaporit disebabkan karena terjadinya reaksi addisi. Secara teori, warna tersusun dari gugus kromofor, antara lain gugus nitroso $(-\mathrm{N}=\mathrm{O})$, gugus azo $(-\mathrm{N}=\mathrm{N}-)$, gugus karbonil $(>\mathrm{C}=\mathrm{O})$, gugus etilen $(>\mathrm{C}=\mathrm{C}<)$, dan gugus azometin $(>\mathrm{C}=\mathrm{N})$. Gugus fungsi tersebut memiliki sifat fisik tidak berwarna, namun apabila berikatan dengan senyawa karbon rantai panjang atau rantai aromatik atau pun berikatan satu sama lain, maka akan terbentuk suatu senyawa yang berwarna ${ }^{17}$. Untuk menghilangkan sifat warna, maka ikatan pada gugus chromophore itu sendiri atau ikatan dengan rantai yang lain harus diubah melalui reaksi addisi. Kaporit dalam air akan mengurai dan menghasilkan gas $\mathrm{Cl}_{2}$ (reaksi 1) yang dapat mengubah ikatan rangkap zat warna menjadi ikatan tunggal (reaksi 2).

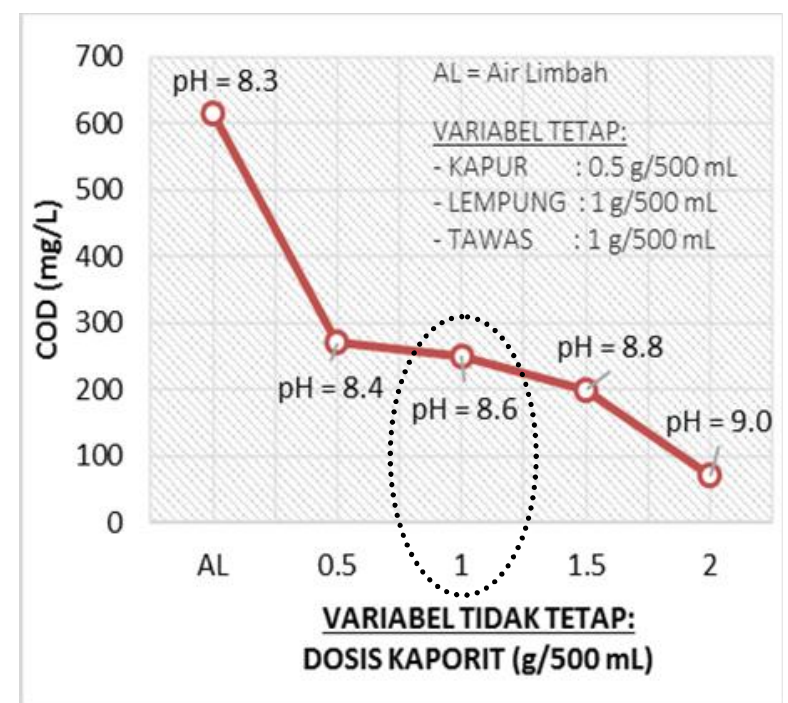

Gambar 2. Penurunan kandungan COD

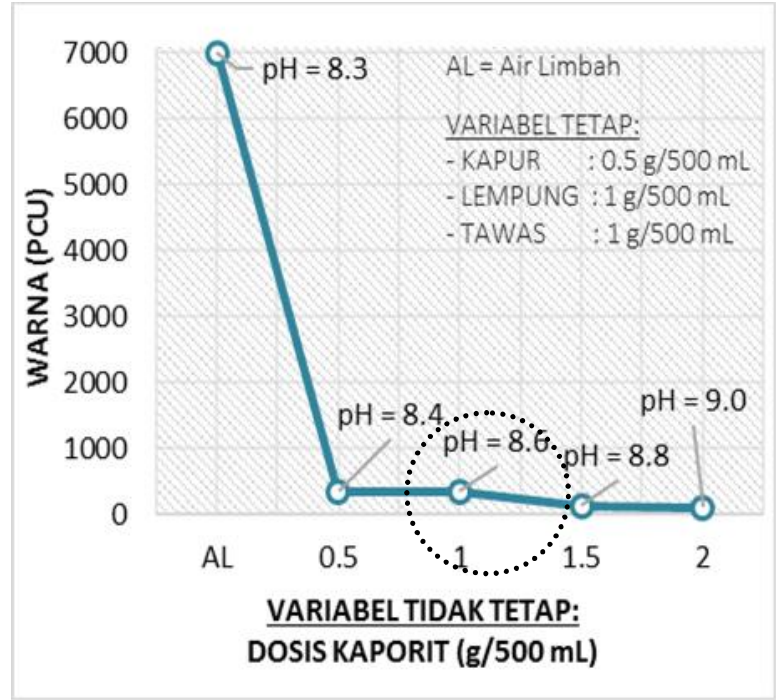

Gambar 3. Penurunan intensitas warna

$\mathrm{Cl}_{2}$ dari kaporit (reaksi 2) bereaksi dengan $\mathrm{C}$ ikatan rangkap dua pada zat warna melalui reaksi addisi membentuk senyawa $\mathrm{C}$ ikatan tunggal bermuatan $\delta+$ (delta positif). Hal ini terjadi karena elektronegatifitas klorida sangat tinggi, sehingga elektron tertarik kearah atom klor. Selanjutnya, karbon yang bermuatan $\delta+$ akan menarik partikelpartikel tersuspensi yang bermuatan negatif (berasal dari penambahan lempung). Proses ini kemudian 
Pengolahan Air Limbah Tekstil Melalui Proses Koagulasi - Flokulasi dengan Menggunakan Lempung Sebagai Penyumbang Partikel Tersuspensi, Studi Kasus: Banaran, Sukoharjo dan Lawean, Kertosuro, Jawa Tengah (Anna Fadliah Rusdi, dkk)

akan menghasilkan suatu zatyang dibungkus dengan muatan negatif dari partikel-partikel tersuspensi. Zat ini kemudian diendapkan melalui proses koagulasi - flokulasi setelah penambahan tawas $\left(\mathrm{Al}^{3+}\right)$. Dengan demikian, kandungan $\mathrm{COD}$ dan intensitas warna dalam air limbah akan turun konsentrasinya.

Reaksi 1:

$2 \mathrm{Ca}(\mathrm{OCl})_{2}+2 \mathrm{H}_{2} \mathrm{O} \rightarrow 2 \mathrm{Ca}(\mathrm{OH})_{2}+2 \mathrm{Cl}_{2}$ (gas) $+\mathrm{O}_{2(\mathrm{gas})}$

Reaksi 2:

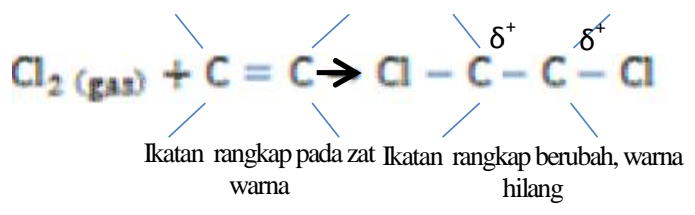

\section{Penentuan dosis kapur $(\mathrm{CaO})$}

Hasil analisis $\mathrm{pH}, \mathrm{COD}$, dan warna pada proses koagulasi - flokulasi kedua ini ditampilkan pada Gambar 4 dan 5.Gambar 6 memperlihatkan penurunan COD pada masing-masing dosis kapur: (i) tanpa penambahan kapur, kadar COD turun dari $615 \mathrm{mg} / \mathrm{L}$ menjadi $220 \mathrm{mg} / \mathrm{L} \quad$ (64\%); (ii) penambahan $0.1 \mathrm{~g}$, kadar COD turun menjadi 190 $\mathrm{mg} / \mathrm{l}$ (69\%); (iii) penambahan $0.2 \mathrm{~g}$, COD turun menjadi $170 \mathrm{mg} / \mathrm{L}$ (72\%); (iv) penambahan $0.3 \mathrm{~g}$, COD turun menjadi $130 \mathrm{mg} / \mathrm{L}$ (79\%); dan (v) penambahan $0.4 \mathrm{~g}$, COD turun menjadi $100 \mathrm{mg} / \mathrm{L}$ (84\%). Sementara itu, penurunan warna tidak seiring dengan jumlah kapur yang ditambahkan, yakni: (i) intensitas warna tanpa penambahan kapur turun dari 7000 PCU menjadi 115 PCU (98\%); (ii) penambahan $0.1 \mathrm{~g}$ dan $0.2 \mathrm{~g}$, intensitas warna turun menjadi 50 PCU (99\%); (iii) penambahan $0.3 \mathrm{~g}$, turun menjadi 45 PCU (99\%), dan (iv) penambahan $0.4 \mathrm{~g}$, warna turun menjadi $60 \mathrm{PCU}(99 \%)$ (Gambar 7).

Penurunan kadar COD tertinggi adalah saat penambahan kapur $0.5 \mathrm{~g}$, sedangkan penurunan intensitas warna yang tinggi adalah pada penambahan kapur sebesar 0.3 g. Pada saat penambahan kapur lebih besar daripada $0.3 \mathrm{~g}$ penurunan intensitas warna tidak sebesar dosis sebelumnya. Hal ini dikarenakan penambahan kapur yang melebihi kebutuhan akan meningkatkan kekeruhan pada air limbah, sehingga pada saat analisis spektofotometri sinar tampak nilai yang terbaca lebih tinggi daripada semestinya.

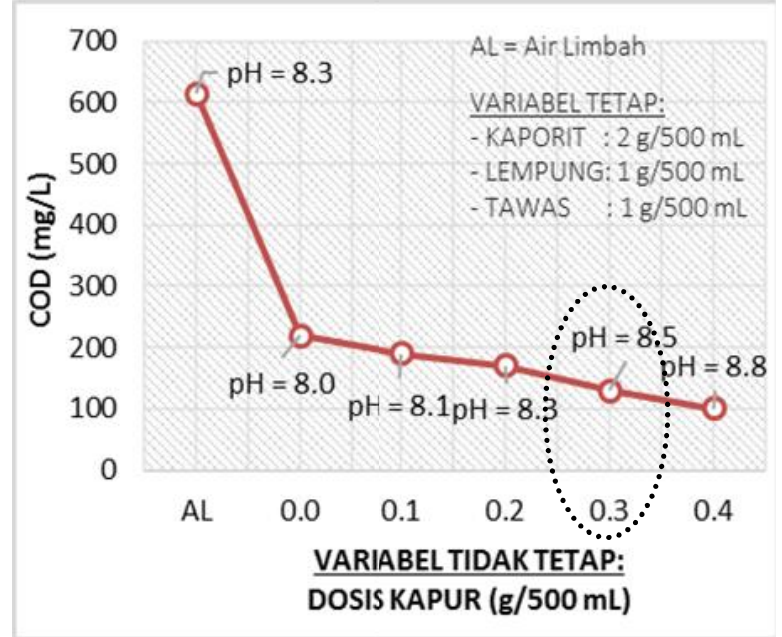

Gambar 4. Penurunan kandungan COD

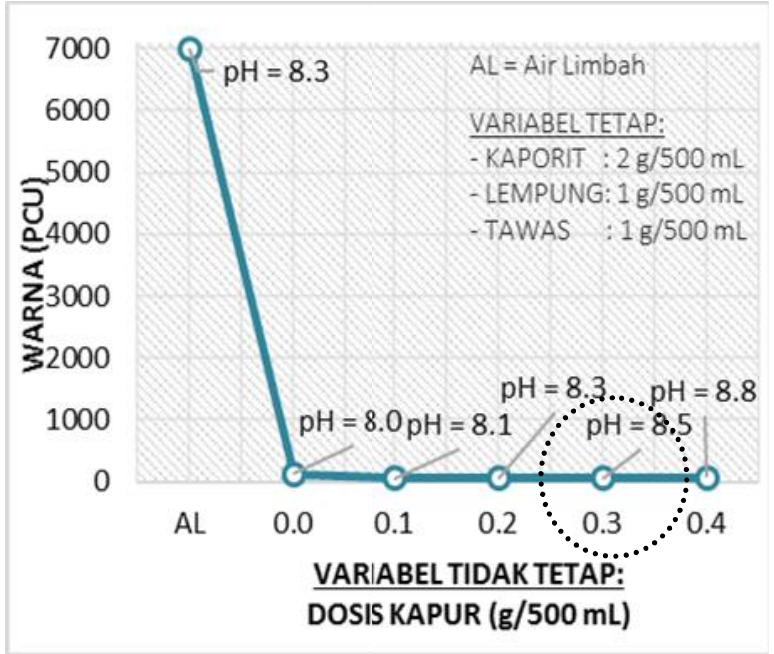

Gambar 5. Penurunan intensitas warna

Setelah penambahan kapur, $\mathrm{pH}$ air limbah rata-rata meningkat menjadi 11 hingga 12 . Kapur tohor $(\mathrm{CaO})$ di dalam air membentuk senyawa kalsium hidroksida $\left(\mathrm{Ca}(\mathrm{OH})_{2}\right)$ yang bersifat basa dan dalam air terurai menjadi dua ion $\mathrm{OH}^{-}$dan ion $\mathrm{Ca}^{2+}$ (reaksi 3). Ion hidroksida $\left(\mathrm{OH}^{-}\right)$akan meningkatkan $\mathrm{pH}$ air limbah.

Reaksi 3:

$\mathrm{CaO}+\mathrm{H}_{2} \mathrm{O} \rightleftharpoons \mathrm{Ca}(\mathrm{OH})_{2} \rightleftharpoons \mathrm{Ca}^{2+}+2 \mathrm{OH}^{-}$

Suasana basa juga berfungsi untuk mengefektifkan koagulan tawas. Hal ini terjadi karena dalam suasana basa, $\mathrm{Al}^{3+}$ di dalam air terhidrolisis membentuk ion kompleks bermuatan positif (reaksi 4), ion ini memiliki kemampuan untuk menyerap permukaan partikel-partikel tersuspensi yang bermuatan negatif. ${ }^{18,19,20}$ 
Reaksi 4:

$\mathrm{Al}^{3+}+3 \mathrm{OH}^{-} \rightarrow \mathrm{Al}(\mathrm{OH})_{3}$ mengendap

$6 \mathrm{Al}^{3+}+15 \mathrm{OH}^{-} \rightarrow \mathrm{Al}_{6}(\mathrm{OH})_{15}^{3+}$ larut

$7 \mathrm{Al}^{3+}+170 \mathrm{H}^{-} \rightarrow \mathrm{Al}_{7}(\mathrm{OH})_{17}^{4+}$ larut

$8 \mathrm{Al}^{3+}+20 \mathrm{OH}^{-} \rightarrow \mathrm{Al}_{8}(\mathrm{OH})_{20}^{4+}$ larut

\section{Penentuan dosis lempung}

Lempung yang digunakan termasuk dalam kategori liat berdebu dengan komposisi sebagai berikut: (i) $14 \%$ pasir kasar; (ii) $2 \%$ pasir halus; (iii) 44\% debu; dan (iv) 40\% liat. Hasil analisis COD dan intensitas warna pada penentuan dosis lempung ditampilkan pada Gambar 6 dan 7. Kandungan COD pada setiap variasi lempung memiliki nilai yang sama, yakni turun menjadi $80 \mathrm{mg} / \mathrm{L}$. Sementara intensitas warna pada setiap variasi lempung turun menjadi: (i) 110 PCU, saat penambahan $1.5 \mathrm{~g}$;(ii) $120 \mathrm{PCU}$, saat penambahan $2.5 \mathrm{~g}$; (iii) $130 \mathrm{PCU}$, saat penambahan $2.5 \mathrm{~g}$; dan (iv) $140 \mathrm{PCU}$, saat penambahan $3 \mathrm{~g}$. Terlihat bahwa semakin banyak penambahan lempung menyebabkan semakin berkurang penurunan warna. Sama halnya dengan kapur, penambahan lempung yang melebihi kebutuhan akan meningkatkan kekeruhan yang selanjutnya dalam analisis spektofotometri sinar tampak akan terbaca sebagai intensitas warna.

Penambahan lempung tidak memberikan perubahan pada $\mathrm{pH}$. pH air limbah berkisar 9 . Ukuran flok yang terbentuk relatif sama antara keempat variasi dosis yang ditambahkan, yakni $\pm 0.3 \mathrm{~cm}$. Dari hasil analisis parameter COD, warna, dan $\mathrm{pH}$ ditetapkan dosis optimum lempung yang digunakan untuk percobaan selanjutnya adalah $1 \mathrm{~g}$ dalam $500 \mathrm{~mL}$ air limbah.

Lempung adalah bahan yang sangat penting dalam proses koagulasi - flokulasi. Lempung merupakan material yang terdiri dari mineral kaya alumina, silika, dan air. Mineral lempung berukuran sangat kecil (lebih kecil dari 2 mikron) dan merupakan partikel yang aktif secara kimiawi. ${ }^{21}$ Kandungan partikel-partikel tersuspensi merupakan syarat utama terjadinya proses koagulasi flokulasi. ${ }^{13}$ Lempung yang ditambahkan dalam air limbah memiliki kandungan debu dan liat yang tinggi, masing-masing 40\% dan 44\%. Debu dan liat inilah yang menjadi partikel-partikel tersuspensi dalam air limbah yang diproses.

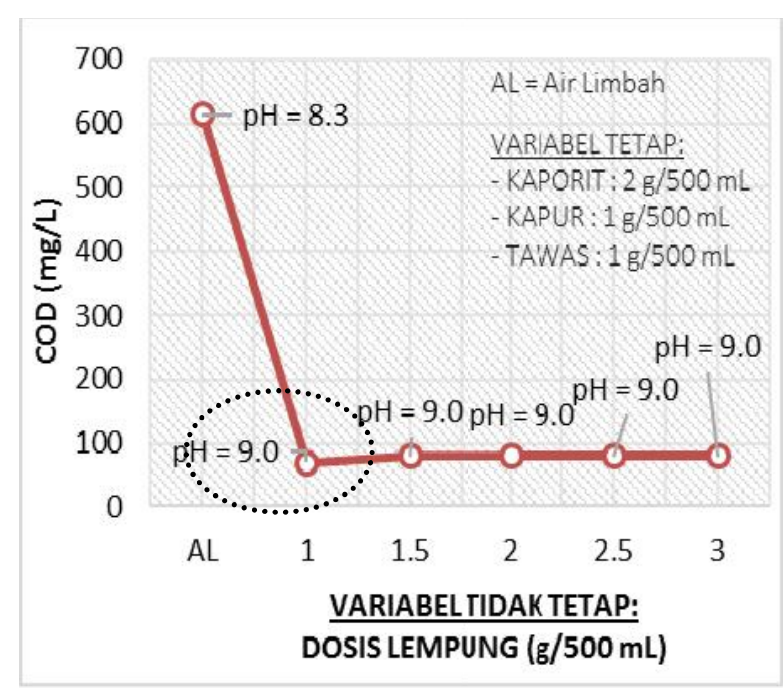

Gambar 6.Penurunan kandungan COD

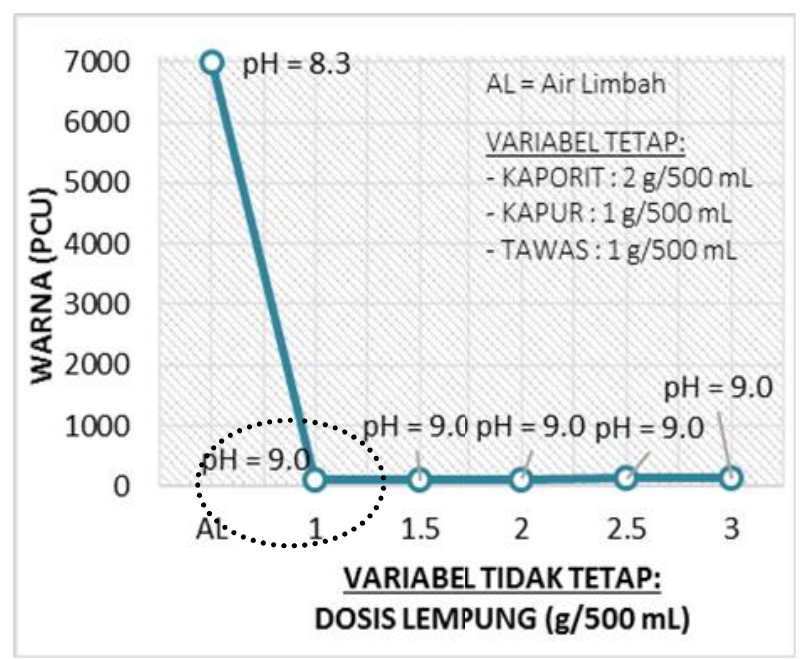

Gambar 7. Penurunan intensitas warna

\section{Penentuan dosis tawas}

Dosis optimum tawas sebagai koagulan telah tergambar pada penentuan dosis sebelumnya, yakni $1 \mathrm{~g} / 500 \mathrm{~mL}$. Hasil analisis kualitas limbah untuk setiap variasi dosis tawas disajikan pada Gambar 8 dan 9. Gambar 8 memperlihatkan kandungan COD pada dosis tawas $0.5 \mathrm{~g}$ turun menjadi $140 \mathrm{mg} / \mathrm{L}$ (78\%), kemudian pada dosis $1 \mathrm{~g}$ COD turun menjadi $130 \mathrm{mg} / \mathrm{L}$ (79\%), dan pada dosis $1.5 \mathrm{~g}$ COD turun menjadi $260 \mathrm{mg} / \mathrm{L}$ (58\%). Gambar 9 menunjukkan penurunan intensitas warna yang seiring dengan penurunan COD. Intensitas warna turun menjadi 145 PCU (98\%) pada penambahan tawas $0.5 \mathrm{~g}$, 45 PCU (99\%) pada penambahan tawas $1 \mathrm{~g}$, dan $105 \mathrm{PCU}(99 \%)$ pada penambahan tawas $1.5 \mathrm{~g}$. 


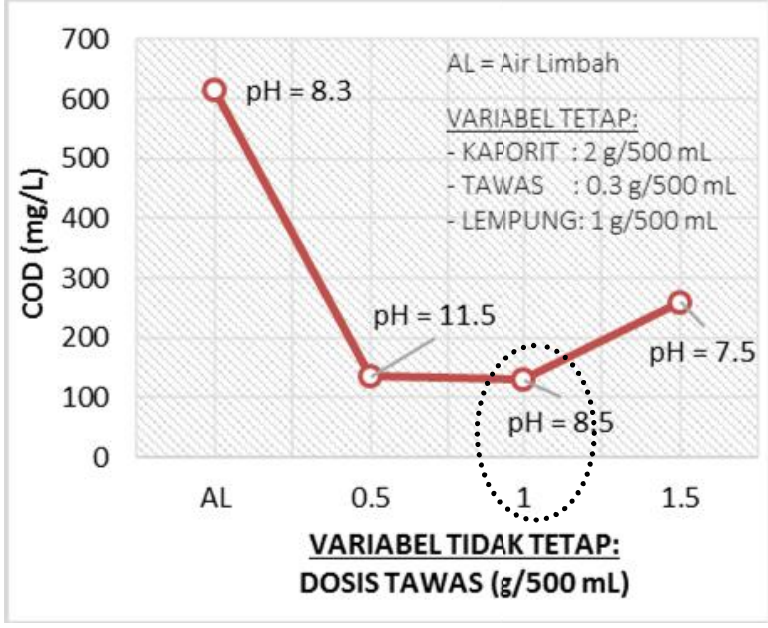

Gambar 8. Penurunan kandungan COD

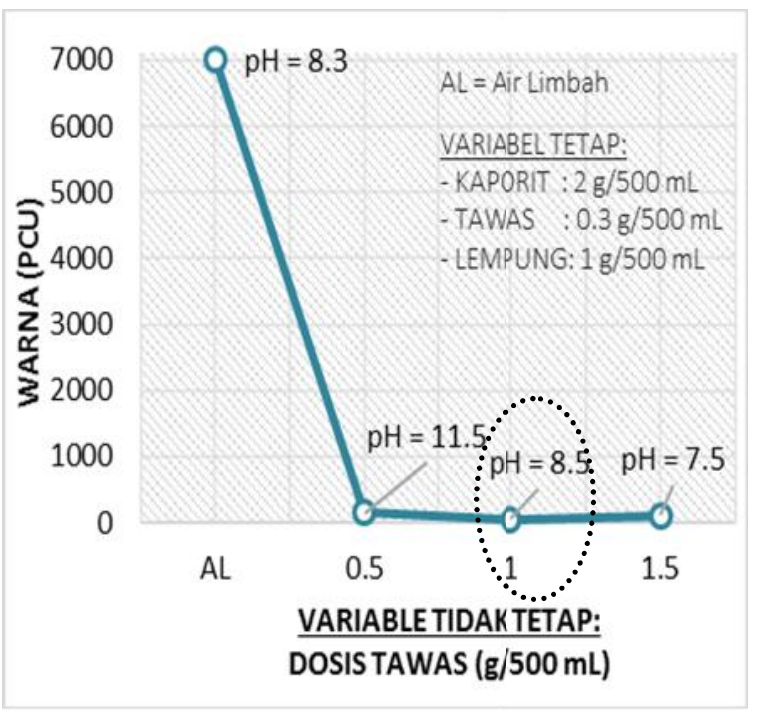

Gambar 9. Penurunan intensitas warna

Telah disebutkan sebelumnya bahwa tawas berperan sebagai koagulan. Tawas dengan rumus kimia $\mathrm{KAl}\left(\mathrm{SO}_{4}\right) \cdot \mathrm{KAl}\left(\mathrm{SO}_{4}\right)_{2}$ dalam larutan terurai menjadi ion-ion $\mathrm{K}_{(\mathrm{aq})}^{+}, \mathrm{Al}^{3+}{ }_{(\mathrm{aq})}$, dan $\mathrm{SO}_{4}{ }^{2-}{ }_{(\mathrm{aq})}$ (reaksi 5). Ion $\mathrm{Al}^{3+}{ }_{\text {(aq) }}$ akan bereaksi dengan air membentuk ion koagulan $\mathrm{Al}(\mathrm{OH})^{2+}$ (reaksi 6). Ion tawas dalam air akan menstabilkan muatan listrik pada permukaan koloid dan partikel sangat ringan lainnya, sehingga semua partikel dapat bergabung membentuk flokberukuran besar yang dapat dipisahkan melalui proses sederhana seperti sedimentasi atau filtrasi. Kandungan pencemar seperti zat organik dan logam akan tergabung ke dalam flok dan ikut mengendap bersama.

Reaksi 5:

$\mathrm{KAl}\left(\mathrm{SO}_{4}\right)_{2(\mathrm{aq}} \rightarrow \mathrm{K}_{(\mathrm{aq})}^{+}+\mathrm{Al}_{(\mathrm{aq})}^{\mathrm{a}+}+2 \mathrm{SO}_{4(\mathrm{aq})}^{3+}$

Reaksi 6:

$\mathrm{Al}_{(\mathrm{aq})}^{3+}+\mathrm{H}_{2} \mathrm{O} \rightarrow \mathrm{Al}(\mathrm{OH})^{2+}+\mathrm{H}^{+}$
Selain berperan sebagai koagulan, tawas juga dapat membantu menurunkan $\mathrm{pH}$ air limbah. Saat penambahan kapur, pH meningkat menjadi 11 hingga 12 , nilai $\mathrm{pH}$ ini tidak memenuhi baku mutu. Namun, pada penambahan tawas $1 \mathrm{~g}$ dan $1.5 \mathrm{~g}, \mathrm{pH}$ air limbah dapat diturunkan menjadi 8.5 dan 7.5. Hal ini terjadi karena ion $\mathrm{H}^{+}$yang terbentuk dari reaksi 6 dapat menurunkan nilai $\mathrm{pH}$ air limbah. ${ }^{22}$

Berdasarkan penurunan COD dan warna, serta nilai $\mathrm{pH}$ akhir limbah, maka dosis optimum tawas yang dipilih adalah $1 \mathrm{~g}$. Dengan demikian, dosis optimum untuk pengolahan $500 \mathrm{~mL}$ air limbah dengan proses koagulasi - flokulasi adalah: (i) $2 \mathrm{~g}$ untuk dosis optimum kaporit; (ii) $0.3 \mathrm{~g}$ untuk dosis optimum kapur; (iii) $1 \mathrm{~g}$ untuk dosis optimum lempung; dan (iv) $1 \mathrm{~g}$ untuk dosis optimum tawas. Kemudian, dilakukan pengulangan pengolahan air limbah sebanyak 3 kali dengan menggunakan dosis optimum dan diperoleh hasil yang relatifsama dengan rata-rata kadar COD $130 \mathrm{mg} / \mathrm{L}$, intensitas warna $45 \mathrm{PCU}$, dan nilai $\mathrm{pH} 8.5$.

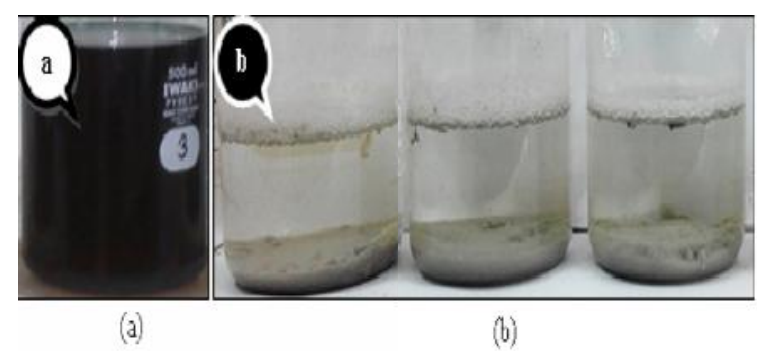

Gambar 10. (a) Air limbah sebelum diolah; (b) Air limbah setelah diolah

Gambar 10 menunjukkan air limbah industri tekstil yang akan diolah (a) dan setelah diolah (b). Secara visual terlihat bahwa air limbah menjadi bening dan tidak berwarna. Dilihat dari kandungan COD yang telah turun dari $615 \mathrm{mg} / \mathrm{L}$ menjadi 130 $\mathrm{mg} / \mathrm{L}$ dan telah memenuhi baku mutu limbah (150 $\mathrm{mg} / \mathrm{L}$ ), maka air limbah dipandang aman untuk dibuang ke lingkungan. Selain itu, intensitas warna pun menunjukkan penurunan yang signifikan, yakni dari 7000 PCU menjadi 45 PCU.

\section{KESIMPULAN}

Dalam rangkaian pengolahan air limbah melalui proses koagulasi- flokulasi, sesaat setelah penambahan kaporit warna air limbah yang pekat dan bening berubah secara signifikan menjadi hampir tidak berwarna. Sifat bening ini mencerminkan kandungan partikel-partikel tersuspensi yang sangat rendah. Air limbah dengan kondisi ini tidak dapat diolah melalui proses koagulasi-flokulasi tanpa penambahan partikelpartikel tersuspensi. Pada penelitian ini, partikelpartikel tersuspensi dalam limbah yang diolah berasal dari penambahan lempung dengan 
kandungan liat $40 \%$ dan debu $44 \%$.Hasil yang diperoleh menunjukkan pada dosis $2 \mathrm{~g}$ kaporit, 0.3 g kapur, $1 \mathrm{~g}$ lempung, dan $1 \mathrm{~g}$ tawas dalam $500 \mathrm{~mL}$ air limbah, telah berhasil menurunkan kandungan COD dari $615 \mathrm{mg} / \mathrm{L}$ menjadi $130 \mathrm{mg} / \mathrm{L} \mathrm{(79} \mathrm{\% );}$ warna dari 7000 PCU menjadi 45 PCU (99 \%); dan pH 8.5. Nilai COD $130 \mathrm{mg} / \mathrm{L}$ dan $\mathrm{pH} 8.5$ telah memenuhi baku mutu limbah cair tekstil untuk dibuang ke lingkungan. Warna belum tercantum dalam bakumutu limbah, namun dengan kondisi air limbah yang bening dan tidak berwarna maka limbah telah memenuhi syarat dari segi estetika.

\section{UCAPAN TERIMAKASIH}

Penulis mengucapkan terimakasih pada Pusat Penelitian Geoteknologi atas kesempatan untuk melakukan penelitian dengan judul "Studi Konsep Pengendalian Pencemaran Limbah Industri Kecil Pencelupan dan Penyepuhan - pada Air Tanah: di Daerah Gianyar dan Karangasem (Bali) dan Sukoharjo/Solo (Jawa Tengah)", kepada Bpk. Dady Sukmayadi, Bpk. Wahyu Purwoko, dan Bpk. Aep Sofyan atas bantuan selama proses laboratorium, serta rekan-rekan peneliti dan litkayasa yang tergabung dalam tim penelitian ini.

\section{PUSTAKA}

1. Freitas, T.K.F.S. Optimization of CoagulationFlocculation Process for Treatment of Industrial Textile Wastewater using okra (a. esculentus) Mucilage as Natural Coagulant. Industrial Crops and Products 76, 538544(2015).

2. World Bank. World Development Indicators Table 3.6: Water Pollution. The World Bank. USA(2012).

3. Verma, A.K., et. al. A Review on Chemical Coagulation/Flocculation Technologies for Removal of Colour from Textile Wastewaters. Journal of Environmental Management 93, 154 $-168(2012)$.

4. Jager, D.D., et al. Colour Removal from Textile Wastewater Using a Pilot-Scale DualStage MBR and Subsequent RO System. Separation and Purification Technology 135, 135 - 144 (2014).

5. Holkar, C.R., et. al. A Critical Review on Textile Wastewater Treatments: Possible Approaches. Journal of Environmental Management 182, 351 - 366 (2016).

6. Akbari, A., et al. Treatment of Textile Dye Effluent Using a Polyamide-Based NanoFiltration Membrane. Chemical Engineering and Processing 41, 601 609(2002).
7. Rusydi, A.F., Marganingrum, D., Suherman, D., dan Sumawijaya, M. Pencemaran Airtanah Bebas Akibat Industri Pencelupan di Kampung Banaran, Sukoharjo, Jawa Tengah. Prosiding, Pemaparan Hasil Penelitian Puslit Geoteknologi (2014).

8. Sumawijaya, N., et al. Studi Konsep Pengendalian Pencemaran Limbah Industri Kecil - Pencelupan dan Penyepuhan - Pada Airtanah: di Daerah Gianyar dan Karangasem (Bali) dan Sukoharjo/Solo (Jawa Tengah). Laporan Penelitian DIPA Tematik. Pusat Penelitian Geoteknologi, LIPI (2013).

9. Suripin. Pengembangan Sistem Drainase yang Berkelanjutan. Andi Offset, Yogyakarta (2004).

10. Liang, C. Z., et al. Treatment of Highly Concentrated Wastewater Containing Multiple Synthetic Dyes by a Combined Process of Coagulation/Flocculation and Nanofiltration. Journal of Membrane Science 469, 306 315(2014).

11. Faust, S.D.dan O.M. Aly. (1998). Chemistry of Water Treatment. Lewis Publisher. USA.

12. Howe, J. K., et al. (2012). Principle of Water Treatment. John Wiley and Sons, Inc. New Jersey.

13. Suherman, D. dan N. Sumawijaya. Menghilangkan Warna dan Zat Organik Air Gambut dengan Metode Koagulasi - Flokulasi Suasana Basa. Riset Geologi dan Pertambangan Vol 23 (2), 125 - 137(2013).

14. Standard Method. The Examination of Water and Wastewater $21^{\text {st }}$ edition. American Public Health Association. Washington (2005).

15. Kementerian Lingkungan Hidup. Keputusan Menteri Lingkungan Hidup No. 51 tentang Baku Mutu Limbah Cair Bagi Kegiatan Industri. Lampiran A-IX. Jakarta (1995).

16. Vickerstaff, T. The Physical Chemistry of Dyeing $2^{\text {nd }}$ edition. Oliver \& Boyd,London (1954).

17. Bahl, B.S. dan A. Bahl.. Advanced Organic Chemistry. S. Chand \& Company Ltd., Lam Nagar. New Delhi. 1279 (1979).

18. Ravina, L. Everything You Want to Know About Coagulation and Flocculation, Zeta Meter, Inc. Staunton, Virginia. Faust, S.D dan O.M. Aly., 1998. Chemistry of Water Treatment. Lewis Publisher. USA (1993).

19. Jiao, R., et.al. Influence of Coagulation Mechanisms on The Residual Aluminium The Roles of Coagulant Species and MW of Organic Matter. Journal of Hazardous Materials 290, 16-25 (2015). 
Pengolahan Air Limbah Tekstil Melalui Proses Koagulasi - Flokulasi dengan Menggunakan Lempung Sebagai Penyumbang Partikel Tersuspensi, Studi Kasus: Banaran, Sukoharjo dan Lawean, Kertosuro, Jawa Tengah (Anna Fadliah Rusdi, dkk)

20. Tang, H., Xiao, F., dan Wang, D. Speciation, Stability, and Coagulation Mechanisms of Hydroxyl Aluminum Clusters Formed by PACl and Alum: A Critical Review. Advances in Colloid and Interface Science 226, 7885(2015).
21. Hillier, S. Clay Mineralogy, in GV Middleton, MJ Church, M Coniglio, LA Hardie, and FJ Longstaffe eds. Encyclopaedia of sediments and sedimentary rocks. Kluwer Academic Publishers. Dordrecht, 139-142 (2003).

22. Goeswono, S. Sifat dan Ciri Tanah, Bahan Bacaan Kuliah.(1979). 
Arena Tekstil Vol. 31 No. 2, 2016: 105-114 